\title{
Dietary Supplementation of $\kappa$-Carrageenan to Improve the Physio-Chemical and Functional Properties of White Bread
}

\author{
Maya Raman, Ammu Dinakaran*, Akshaya Ravindran, Thazhakot Vasunambisan Sankar, \\ Teralandur Krishnaswamy Srinivasa Gopal \\ Center of Excellence in Food Processing Technology, Kerala University of Fisheries and Ocean Studies, Cochin, India \\ Email: *ammu.dinakaran@gmail.com
}

How to cite this paper: Raman, M., Dinakaran, A., Ravindran, A., Sankar, T.V. and Gopal, T.K.S. (2019) Dietary Supplementation of $\kappa$-Carrageenan to Improve the Physio-Chemical and Functional Properties of White Bread. Food and Nutrition Sciences, 10, $997-1010$

https://doi.org/10.4236/fns.2019.108071

Received: July 23, 2019

Accepted: August 18, 2019

Published: August 21, 2019

Copyright $\odot 2019$ by author(s) and Scientific Research Publishing Inc. This work is licensed under the Creative Commons Attribution International License (CC BY 4.0).

http://creativecommons.org/licenses/by/4.0/

\begin{abstract}
Fiber intake improves gut health and prevents non-communicable diseases. The current study investigates the substitution of carrageenan in white bread and evaluates its effect on the physiochemical and structural characteristics of bread. The $100 \%$ wheat flour was used as control and the test sample contained $4 \%$ carrageenan. The physio-chemical analysis showed that carrageenan-substitution improved the hydration properties of the flour (WHC-1.33 $\mathrm{g} / \mathrm{g} ; \mathrm{SC}-3.50 \mathrm{ml} / \mathrm{g}$ ). Carrageen substituted bread had reduced the loaf volume. The fiber content in carrageenan-substituted bread was noticeably higher (9.4 g\%) than control (3.5 g\%). Crude lipid (4.6 g\%) and protein (7.0 $\mathrm{g} \%)$ content improved with carrageenan-substitution. The mineral contents $(\mathrm{Na}, \mathrm{K}, \mathrm{Mg}, \mathrm{Ca}, \mathrm{Fe}$, and $\mathrm{Zn}$ ) were increased in carrageenan-breads. The texture profile analysis showed a decreased hardness (H1-92.3 N, H2-62.5 N) and improved springiness $(5.3 \mathrm{~mm})$ in carrageenan-bread.
\end{abstract}

\section{Keywords}

Carrageenan, Wheat Flour, Bread, Texture Profile Analysis, Physio-Chemical Properties

\section{Introduction}

Bread is one of the oldest functional foods and is an important part of total daily food consumed all over the world; even though, in India, it is a secondary staple food. Nutritionally, it is a good source of fibers (non-starch polysaccharides including arabinoxylans), minerals and vitamins. It has gained considerable attention due to its nutritional and health benefits [1]. Functional bakery products are 
becoming increasingly popular. Cereals (rye, corn, rice and oats), grains (buckwheat, amaranth and quinoa), sprouts, etc. were reported to improve the nutritional profile of bread by increasing the concentration of polyphenols, ferulic acid, glutathione, plant sterols, vitamins, minerals, etc. [2] [3] [4].

Several potential terrestrial and marine hydrocolloids have been proposed to increase the functionality and health benefits of bakery products especially bread including alginates, carrageenans, agar, guar gum, methylcellulose, carboxymethylcellulose (CMC) and hydroxypropylmethylcellulose (HPMC) [5] [6]. Functional and nutritional property of bakery products were reported to be improved by hydrocolloids such as polysaccharides [7], marine functional ingredients [8] [6], protein sources such as cereals, tubers, corn gluten, corn germ and rice bran [9], natural antioxidants [10] [11], plant extracts such as green tea [12], grape seed extracts [13] and prebiotics [14] [15]. The alginates (from brown algae) and carragenates (from red algae) are the few prospective hydrocolloids that were reported to be rich in bioactive compounds and dietary fibers; and impart functional effects such as modification of dough/batter rheology and keeping quality of finished baked products [16]. These also contribute to high water retention capacity and exhibit fat mimetic properties [17] [18]. These also contribute to antistaling effects [8]. Marine hydrocolloids (polysaccharides), apart from acting as functional ingredient, these were reported to have a positive influence on several health aspects including reducing the risk of colon cancer, constipation, hypertension, hypercholesterolemia, obesity, and diabetes, and enhance immunological activities, antibacterial activity, etc. [19] [20] [21].

$\kappa$-Carrageenan, a marine hydrocolloid, is a common food additive extracted from red algae. Even though, it adds no nutritional value or flavor to foods or beverages, it finds wide application in the food industry because of its unique chemical structure [22] [23] [24] [25]. It serves as a substitute for fat and acts as thickening, gelling and stabilizing agent. In the bakery industry, it has been reported to improve the dough stability [26] and affects the bump area related to the formation of amylase-lipid complex [27]. It also finds application in many processed foods such as frozen pizzas, nutritional bars, canned pet foods, liquid infant formula, etc. [28].

In the present scenario wherein the marine functional bioactive components are becoming popular, carrageenan-incorporated bread could offer a palatable way to incorporate marine fibers in diet and utilize its health benefits. Therefore, the current study investigated the effect of carrageenan supplementation in white bread and its effect on the physiochemical and functional properties of the product. The work is purely innovative and not done elsewhere.

\section{Materials and Methods}

\subsection{Materials}

Commercial wheat flour, active dry yeast, salt, sugar, oil, milk and Vitamin C (food grade) purchased from a local supermarket (Cochin, Kerala, India) were 
used for the bread and dough production. Other analytical grade chemicals used in the experiments were obtained from HiMedia ${ }^{\circledR}$ and Sigma-Aldrich ${ }^{\circledR}$ (Cochin, Kerala, India). Carrageenan (food-grade, $\mathrm{pH} 8.2$, Plate count $<5000$ ) was obtained from Aquarev Industries (Una, Gujarat, India). Water used in the experiments was deionized unless specified otherwise. This work was carried out at Centre of Excellence in Food Processing Technology, Kerala University of Fisheries and Ocean Studies, India.

\subsection{Preparation of Bread}

Bread production was conducted through both straight-dough bread-making method and sponge-and-dough method, with slight modifications [29]. Control samples were prepared by mixing $61.7 \mathrm{~g}$ flour, $0.009 \mathrm{~g}$ yeast, $26.1 \mathrm{~g}$ water, $0.02 \mathrm{~g}$ sugar, $0.00006 \mathrm{~g}$ salt, $0.02 \mathrm{~g}$ refined sunflower oil (enriched with Vitamin A and D), $0.07 \mathrm{~g}$ milk and $50 \mathrm{ppm}$ Vitamin C were taken per $100 \mathrm{~g}$ bread. Carrageen-bread contained all the ingredients including $4 \%$ carrageenan (Table 1). As in straight-dough methods, all the ingredients were combined at once and dough was mixed by hand. The dough was subjected to fermentation for $16 \mathrm{~h}$ at $29^{\circ} \mathrm{C}$ (sponge-and-dough method). After leavening, it was molded, proofed at $37^{\circ} \mathrm{C}$ under $80 \%$ relative humidity for $30 \mathrm{~min}$ and finally baked for $30 \mathrm{~min}$ at $180^{\circ} \mathrm{C}$ (Morphy Richards Oven-Toaster-Griller 28 RSS, Cochin Kerala, India). After baking, the breads were cooled for $2 \mathrm{~h}$ at $20^{\circ} \mathrm{C}$, packed in butter paper (350 $\mathrm{g} / \mathrm{bag}$ ) and then stored at $20^{\circ} \mathrm{C}$ (Figure 1).

\section{Analysis of Physiochemical Properties}

\subsection{Physical Properties of Flour}

\subsubsection{Measurements of $\mathrm{pH}$}

The $\mathrm{pH}$ of bread samples was measured by a $\mathrm{pH}$ meter (Eutech Instruments $\mathrm{pH}$ 510, CyberScan, India) using Approved Methods [29]. Bread samples were cut and mixed with distilled water in 1:10 ratio and stirred for $30 \mathrm{~min}$. The supernatant was collected and $\mathrm{pH}$ values were recorded.

Table 1. Composition of bread (control and carrageenan-bread).

\begin{tabular}{ccc}
\hline Composition & Control bread & Carrageenan-bread \\
\hline Flour (g) & 61.4 & 59.9 \\
Yeast (g) & 0.9 & 0.8 \\
Water (g) & 26 & 25.3 \\
Sugar (g) & 2.1 & 2 \\
Salt (g) & 0.6 & 0.6 \\
Oil (g) & 1.8 & 1.7 \\
Milk (g) & 7.4 & 7.2 \\
Vitamin C (g) & 0.009 & 0.009 \\
Carrageenan & 0 & 2.4 \\
\hline
\end{tabular}




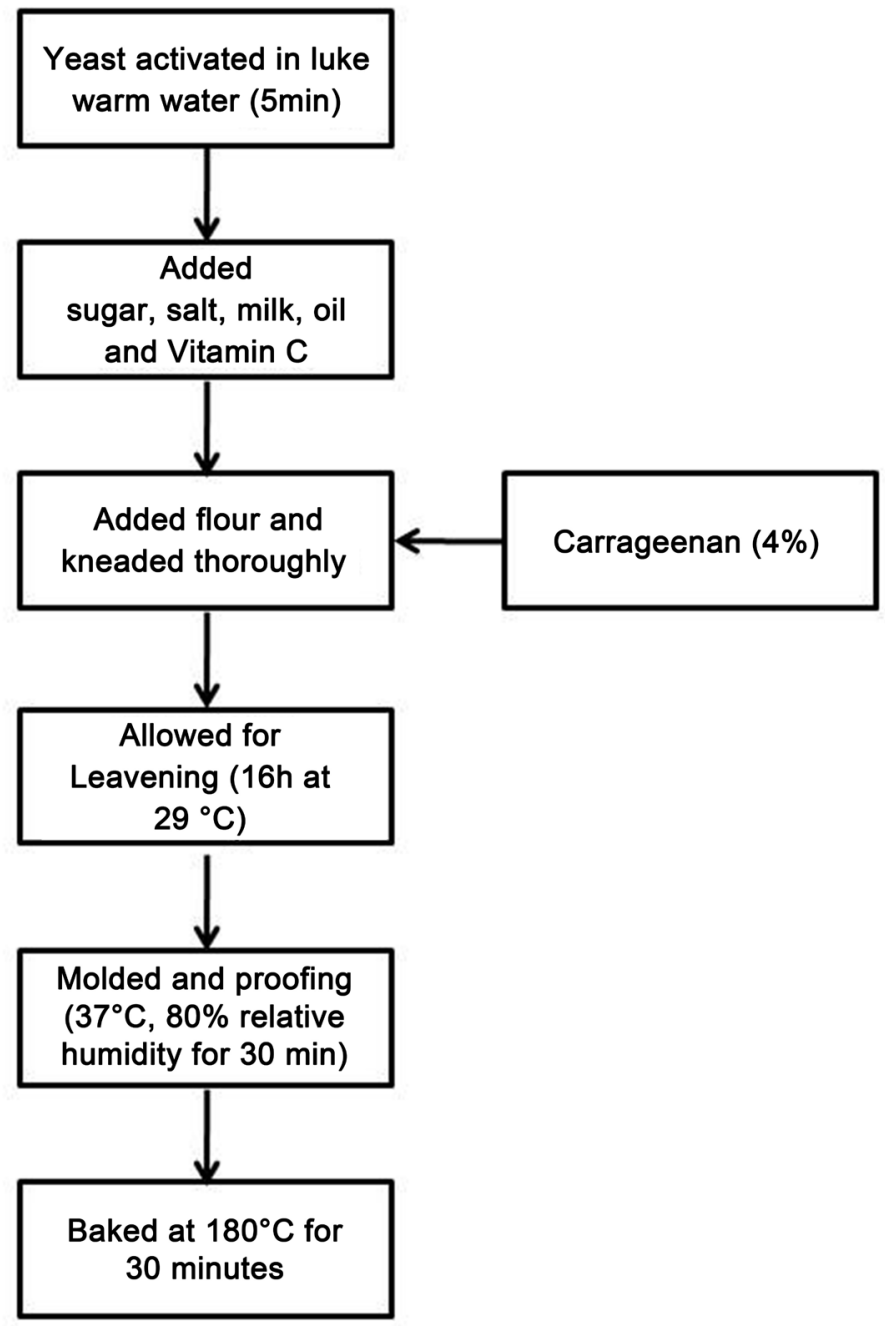

Figure 1. Protocol for the preparation of carrageenan-incorporated bread.

\subsubsection{Measurement of Bulk Density}

A clean, dry $10 \mathrm{ml}$ graduated measuring cylinder was weighed and filled with $2 \mathrm{~g}$ flour sample, which were shaken slightly and the volume was recorded. The weight of the cylinder and the contents were measured and bulk density was calculated [30].

$$
\operatorname{Bulk} \operatorname{density}(\mathrm{g} / \mathrm{ml})=\text { Sample weight } / \text { Sample volume }
$$

\subsubsection{Measurement of Packed Density}

A clean dry $10 \mathrm{ml}$ measuring cylinder was filled with $2 \mathrm{~g}$ flour sample, which was tapped until there was no further reduction in volume (packed tightly). The packed volume was recorded and packed density was calculated [30].

$$
\text { Packed density }(\mathrm{g} / \mathrm{ml})=\text { Sample weight } / \text { Packed volume }
$$

\subsubsection{Water Holding Capacity (WHC)}

The WHC of flour samples were measured according to [30]. Approximately, $1 \mathrm{~g}$ of sample was weighed into a $50 \mathrm{~mL}$ graduated test tube. Around $30 \mathrm{ml}$ of dis- 
tilled water was added and equilibrated for $18 \mathrm{~h}$ at ambient temperature. Supernatant was discarded and the hydrated residue was weighed. WHC was calculated using the formula:

WHC (g/g) = Residue hydrated weight - Residue dry weight/Residue dry weight

\subsubsection{Swelling Capacity}

Swelling capacity (SC) of flour samples was determined according to [30]. Approximately, $1 \mathrm{~g}$ of flour sample was hydrated with $50 \mathrm{ml}$ of distilled water in a graduated tube and equilibrated for $18 \mathrm{~h}$. Volume attained by the flour samples were measured and swelling capacity was calculated.

$$
\mathrm{SC}(\mathrm{ml} / \mathrm{g})=\text { Volume occupied by sample/Dry sample weight }
$$

\subsubsection{Oil Holding Capacity}

Approximately, $1 \mathrm{~g}$ of sample was weighed into a $50 \mathrm{~mL}$ graduated test tube. Around $30 \mathrm{ml}$ of refined sunflower oil was added and equilibrated for $18 \mathrm{~h}$ at ambient temperature. Supernatant was discarded and weight difference was determined to calculate the oil holding capacity (OHC) [31].

OHC $(\mathrm{g} / \mathrm{g})$ = Residue weight with oil - Residue dry weight/Residue dry weight

\subsubsection{Measurement of Loaf Volume and Specific Volume}

The bread was weighed and the volume was measured by the rapeseed displacement method [32]. Briefly, the loaf removed after $15 \mathrm{~min}$ from oven, was put in a metallic container with known volume $\left(V_{C}\right)$. The container was then topped with rapeseed, the loaf was removed and the volume of the rapeseed was noted $\left(V_{R}\right)$. Loaf volume $\left(V_{L}\right)$ was calculated according to the equation

$$
V_{L}(\mathrm{ml})=V_{C}-V_{R}
$$

After cooling for $1 \mathrm{~h}$, the same loaves were weighed $(W)$ and specific volume was calculated, using the formula

$$
V_{S}(\mathrm{ml} / \mathrm{g})=V_{L} / W
$$

\subsubsection{Chemical Characterization}

The moisture (method 925.10), ash (method 923.03), protein ( $\mathrm{N} x$ 6.25) (960.52) (KEL PLUS digestion (KES $06 \mathrm{R}$ ) and distillation systems (DISTYL EM S), M/s Pelican Equipments, Tamil Nadu, India) and lipid contents (2003.05) (SOCS PLUS SCS2 R, M/s Pelican Equipments, Tamil Nadu, India) were determined according to AOAC (2005) [33]. The total dietary fiber (TDF) was determined using FIBRA PLUS FES 02 E (M/s Pelican Equipments, Tamil Nadu, India). Total carbohydrate was determined by phenol-sulfuric acid method [34] (Dubois et al. 1956). The caloric value of the breads was calculated using the Atwater factor formula, where by the major biochemical constituents were converted into calorific values using standard calorific equivalents, i.e., 5.65, 9.45, and 4.20 for proteins, lipids, and carbohydrates, respectively [35].

$$
\text { Calorific value }(\mathrm{kcal} / \mathrm{g})=(5.65 \times P+9.45 \times L+4.20 \times C) / 100
$$


Data were collected on reducing sugar and total sugar using Lane and Eynon method [36] and non-reducing sugar was determined using Hortwitz [37].

Non-reducing sugar $(\%)=($ total sugars $\%-$ reducing sugars $\%) \times 0.95$

\subsubsection{Mineral Content}

Wet digestion method was used for mineral digestion; and accordingly the sample ( $1 \mathrm{~g}$ ) was digested (heating mantle ANTECH, AN-MSH 680, India) with $5 \mathrm{ml}$ concentrated $\mathrm{HNO}_{3}$ solution at $70^{\circ} \mathrm{C}$ for $30 \mathrm{~min}$. After cooling, $5 \mathrm{ml}$ of $30 \%(\mathrm{v} / \mathrm{v})$ $\mathrm{H}_{2} \mathrm{O}_{2}$ solution were added. The heating was continued until clear solution was obtained. This clear solution was made up to $25 \mathrm{ml}$ using deionized water. Blanks were prepared and subjected to analysis to correct final results. The mineral contents were determined by ICP-OES. The Optima 8000 ICP-OES Spectrometer (PerkinElmer, India) was used for measuring the sodium, potassium, calcium, magnesium, iron, copper and zinc. A RF power of 1500 watts, a plasma gas flow rate of $8 \mathrm{~L} / \mathrm{min}$, a shear gas flow rate of $25 \mathrm{~L} / \mathrm{min}$ and a nebulizer gas flow rate of $0.7 \mathrm{~L} / \mathrm{min}$. Prepared sample solutions were introduced into the plasma using auto sampler. Nebulizer and a cyclonic type spray chamber at a flow rate of $1 \mathrm{ml} / \mathrm{min}$. Analytical line of $\mathrm{Na} 589.021 \mathrm{~nm}, \mathrm{~K} 766.490 \mathrm{~nm}, \mathrm{Mg}$ $279.081 \mathrm{~nm}$, Ca $315.889 \mathrm{~nm}$, Fe 259.942 nm, Cu $324.756 \mathrm{~nm}$ and Zn $213.861 \mathrm{~nm}$, were selected and measured.

\subsection{Texture Profile Analysis}

After cooling the bread samples were cut in cubes of $3 \mathrm{~cm} \times 3 \mathrm{~cm}$ size and the texture profile analysis was performed using a TA Plus Texture Analyzer (Lloyd Instruments, UK) equipped with a cylindrical probe of $50 \mathrm{~mm}$ in diameter (test speed: $1 \mathrm{~mm} / \mathrm{s}$, trigger force: $9.8 \mathrm{~N}$ and compression: $48 \%$ ). All values are given as an average of three measurements and the total texture change were evaluated [38].

\subsection{Crumb Color Analysis}

The CIE Lab coordinate of the bread samples (crumb) were determined using Color Flex EZ (Hunterlab, USA) reporting luminosity $\left(L^{*}\right)$, redness $\left(a^{\star}\right)$, and yellowness $\left(b^{*}\right)$. Measurements were done at nine different points within the crumb region and mean values were reported for each sample.

\subsection{Sensory Evaluation}

The sensory evaluation of bread samples was carried out for consumer acceptance and preference by 10-panel members, using a ten-point Hedonic Scale (1 and 10, representing extreme dislike and extreme like, respectively). Coded samples of the same size were served to participants in identical containers.

\subsection{Statistics}

All results are expressed given as means and standard deviation. Analysis of va- 
riance was conducted using one-way ANOVA and Tukey test by pair-wise analysis with significance defined at $\mathrm{p}<0.05$.

\section{Results and Discussion}

\subsection{Physiochemical Characterization of Bread}

The $\mathrm{pH}$ of flours, control and carrageenan-supplemented bread, were near to neutral (6.5 and 7.5, respectively). Supplementation of carrageenan to the flour improved the hydration properties (Water holding capacity-1.33 g/g and Swelling capacity- $3.5 \mathrm{ml} / \mathrm{g}$, respectively). These results were in accordance with earlier reports [39] [40]. The enhanced hydration properties in carrageenan-supplemented bread could be due to the unique chemical structure of the hydrocolloid and its interaction with the flour [39] [40]. Hydrocolloids were reported to weakens the starch structure; thereby, improving the water distribution and retention and softens the bread [41] [8] [42]. Additionally, these modulate the gluten network and create bonds in the dough; consequently, improving the viscoelastic properties of bread to produce breads with higher volumes, better porosity and desired crumb texture [43]. Nevertheless, the oil holding capacity of the control (1.48 $\mathrm{g} / \mathrm{g}$ ) was higher than carrageenan-supplemented bread (1.14 g/g). Carrageenan act as fat replacers and reduce the oil uptake [42].

The size-related parameters of bread such as loaf volume, weight and specific volume indicates the baking time and temperature relationship. The specific volume, is the ratio of the loaf weight and loaf volume, is generally adopted as a more reliable measure of loaf size. Loaf volume is affected by the quantity and quality of ingredients in the flour [44] and proofing time [45] whereas loaf weight is basically determined by the quantity of dough baked and the amount of moisture and carbon dioxide diffused out of the loaf during baking. The loaf weight for control $(124.83 \mathrm{~g})$ is less than carrageenan-supplemented bread (140.13 $\mathrm{g})$, while the loaf volume and specific volume reduced in latter $(130.0 \mathrm{ml}$ and $0.93 \mathrm{ml} / \mathrm{g}$, respectively) than control $(150.0 \mathrm{ml}$ and $1.20 \mathrm{ml} / \mathrm{g}$, respectively). The variation in loaf volume could be attributed mainly to different rate of gas evolution and the extent of starch gelatinization. Carrageenan incorporation possibly weakens the starch structure and softens the bread [8] [42].

The moisture percentage of white bread and carrageenan (hydrocolloid) supplemented bread were $28.6 \%$ and $29.4 \%$, respectively. The ash contents were $1.0 \%$ and $1.5 \%$, while the percentages of protein were $6.9 \%$ and $7.0 \%$, respectively. The percentages of fat content for the bread were $3.0 \%$ and $4.6 \%$, respectively (Table 1). Total carbohydrate contents were $17.8 \%$ and $15.0 \%$, whereas the fiber content were $3.5 \%$ and $9.4 \%$, respectively. Proximate composition analysis indicated that the supplementation of bread with carrageenan improved its fiber and mineral content. Total sugar and non-reducing sugar were significantly $(\mathrm{p}<$ 0.05) high in control (17.0 g\% and $10.7 \mathrm{~g} \%$, respectively) than carrageenan incorporated bread. According to the United State Food and Drug Administration, carrageenan is considered either as food additives or generally recognized as safe 
(GRAS) substances [46]. Hydrocolloids have low calorific value and hence, do not add to the calories [42] [47].

Mineral contents were analyzed using ICP-OES, which indicated that carrageenan-supplemented bread had high amounts of sodium $(2709.6 \mu \mathrm{g} / \mathrm{g}, 53 \%$ $\mathrm{RDA})$, potassium ( $2565.7 \mu \mathrm{g} / \mathrm{g}, 77 \% \mathrm{RDA})$, magnesium $(678.8 \mu \mathrm{g} / \mathrm{g}, 59 \% \mathrm{RDA})$, calcium $(277.9 \mu \mathrm{g} / \mathrm{g}, 70 \%-71 \% \mathrm{AI})$ and iron $(63.1 \mu \mathrm{g} / \mathrm{g}, 84 \% \mathrm{RDA})$, which is significantly higher than control (Na: $2618.8 \mu \mathrm{g} / \mathrm{g}, 51 \% \mathrm{RDA}$ K: $1452.7 \mu \mathrm{g} / \mathrm{g}$, 59\% RDA; Mg: $235.4 \mu \mathrm{g} / \mathrm{g}$, 19\% less than RDA; Ca: $254.6 \mu \mathrm{g} / \mathrm{g}$, 66\% - 67\% RDA; Fe: $51.9 \mu \mathrm{g} / \mathrm{g}, 80 \% \mathrm{RDA})$; copper $(1.2 \mu \mathrm{g} / \mathrm{g})$ and zinc $(4.3 \mu \mathrm{g} / \mathrm{g})$ showed significant decrease in the concentration with the supplementation of carrageenan than control (Cu: $3.3 \mu \mathrm{g} / \mathrm{g}, \mathrm{Zn}: 6.1 \mu \mathrm{g} / \mathrm{g}$ ) (Table 1). Supplementation of carrageenan appreciably contributes to the enrichment of micronutrients.

\subsection{Color Analysis}

The color analysis showed that both breads has similar values for whiteness, yellowness and redness, indicating that the color of the bread were comparable with each other (Table 2). Addition of carrageenan did not alter the $L^{*}, a^{*}$ and $b^{*}$ values of the samples.

\subsection{Texture Profile Analysis}

The texture analysis indicated that both bread had similar hardness profile ranging (Hardness 1, H1: 92.3 - $92.6 \mathrm{~N}$; Hardness 2, H2: 62.5 - 63.4 N). (Table 3). Springiness was high for carrageenan supplemented bread $(5.3 \mathrm{~mm})$ than control $(4.9 \mathrm{~mm})$; however, the chewiness was high for white bread (7.5 kgf.mm). The sensory evaluation indicated that white bread was more preferred by the panel members than carrageenan supplemented bread. Supplementation of the bread with $\kappa$-Carrageenan or hydrocolloid affected the shape of the loaf slice. It increased the width/height ratio, thereby improving the slice shape of fresh bread. Carrageenan supplementation did not affect the crunchiness of the bread. The final baked product had higher softness than control [48]. Storage of bread under refrigeration condition indicated that bread hardness was not affected even after 24 hours. Sensory evaluation revealed the acceptability of the product and the results are shown in Table 3.

Bread represents the most important part of the total daily food consumed. Hydrocolloids such as alginate, carrageenan, etc. modify the bread texture (Figure 2) [46], improve hydration properties and dough rheology [49], and improve the shelf life by retarding the staling process [50] [42].

The decisive effects of hydrocolloids on dough and bread properties depend on several factors including molecular structure, particle size and proportion of hydrocolloids, recipe, dough and bread preparation methods and bread types [51].

\section{Conclusion}

Inclusion of carrageenan together with wheat flour improved the hydration 
Table 2. Physiochemical characterization and color analysis of white bread (control) and carrageenan supplemented white bread (Car-bread), Level of significance $(\mathrm{p}<0.05)$ - a.

\begin{tabular}{|c|c|c|}
\hline & Control & Car-bread \\
\hline \multicolumn{3}{|l|}{ Physical parameters } \\
\hline $\mathrm{pH}$ & 6.5 & 7.5 \\
\hline Loaf weight (g) & 124.83 & 140.13 \\
\hline Loaf volume (ml) & 150.00 & 130.00 \\
\hline Specific volume $(\mathrm{ml} / \mathrm{g})$ & 1.20 & 0.93 \\
\hline Bulk density (g/ml) & 0.40 & 0.41 \\
\hline Packed density $(\mathrm{g} / \mathrm{ml})$ & 0.65 & 0.65 \\
\hline Water holding capacity (g/g) & 1.06 & 1.33 \\
\hline Swelling capacity $(\mathrm{ml} / \mathrm{g})$ & 2.60 & 3.50 \\
\hline Oil holding capacity (g/g) & 1.48 & 1.14 \\
\hline \multicolumn{3}{|l|}{ Chemical parameters $(\mathrm{g} / 100 \mathrm{~g})$} \\
\hline Moisture & $28.6 \pm 0.4$ & $29.4 \pm 0.5$ \\
\hline Ash & $1.0 \pm 0.0$ & $1.5 \pm 0.3$ \\
\hline Fat & $3.0 \pm 0.7$ & $4.6 \pm 0.9$ \\
\hline Protein & $6.9 \pm 0.1$ & $7.0 \pm 0.1$ \\
\hline Carbohydrate & $17.8 \pm 0.5$ & $15.0 \pm 1.0$ \\
\hline Fiber & $3.5 \pm 0.3$ & $9.4 \pm 1.5^{\mathrm{a}}$ \\
\hline Reducing sugar & $5.8 \pm 0.0$ & $6.9 \pm 0.0$ \\
\hline Non-reducing sugar & $10.7 \pm 0.0^{\mathrm{a}}$ & $8.4 \pm 0.0$ \\
\hline Total sugar & $17.0 \pm 0.0^{\mathrm{a}}$ & $15.6 \pm 0.0$ \\
\hline \multicolumn{3}{|l|}{ Mineral content $(\mu \mathrm{g} / \mathrm{g})$} \\
\hline Sodium & 2618.8 & 2709.6 \\
\hline Potassium & 1452.7 & 2565.7 \\
\hline Magnesium & 235.4 & 678.8 \\
\hline Calcium & 254.6 & 277.9 \\
\hline Iron & 51.9 & 63.1 \\
\hline Copper & 3.3 & 1.2 \\
\hline Zinc & 6.1 & 4.3 \\
\hline Calories $(\mathrm{kcal} / \mathrm{g})$ & 1.4 & 1.5 \\
\hline \multicolumn{3}{|l|}{ Color analysis } \\
\hline $\mathrm{L}^{*}$ & $76.4 \pm 1.0$ & $76.7 \pm 1.0$ \\
\hline$a^{*}$ & $1.0 \pm 0.1$ & $1.0 \pm 0.1$ \\
\hline$b^{*}$ & $18.2 \pm 0.3$ & $18.2 \pm 0.3$ \\
\hline
\end{tabular}


Table 3. Texture profile analysis and sensory evaluation of white bread (control) and carrageenan supplemented white bread (Car-bread); Level of significance $(\mathrm{p}<0.05)$ - a.

\begin{tabular}{|c|c|c|}
\hline & Control & Car-Bread \\
\hline \multicolumn{3}{|c|}{ Texture profile analysis (Instrumental) } \\
\hline Hardness1 (N) & $92.6 \pm 14.6$ & $92.3 \pm 10.2$ \\
\hline Hardness2 (N) & $63.4 \pm 10.9$ & $62.5 \pm 7.3$ \\
\hline Cohesiveness & $0.2 \pm 0.0$ & $0.1 \pm 0.0$ \\
\hline Springiness $(\mathrm{mm})$ & $4.9 \pm 0.9$ & $5.3 \pm 0.6$ \\
\hline Springiness Index & $0.5 \pm 0.1$ & $0.6 \pm 0.2$ \\
\hline Gumminess (kgf) & $1.5 \pm 0.7$ & $1.2 \pm 0.3$ \\
\hline Chewiness (kgf.mm) & $7.5 \pm 3.3$ & $6.5 \pm 1.6$ \\
\hline Adhesiveness (kgf.mm) & $-1.3 \pm 0.3$ & $-1.4 \pm 0.2$ \\
\hline \multicolumn{3}{|l|}{ Sensory evaluation } \\
\hline Taste & $7.0^{\mathrm{a}}$ & 6.6 \\
\hline Texture & 7.1 & 7.0 \\
\hline Aroma & $7.8^{\mathrm{a}}$ & 6.6 \\
\hline Crumb color & $7.8^{\mathrm{a}}$ & 7.4 \\
\hline Crust color & 7.7 & 7.4 \\
\hline Overall acceptability & $7.5^{\mathrm{a}}$ & 7.0 \\
\hline
\end{tabular}
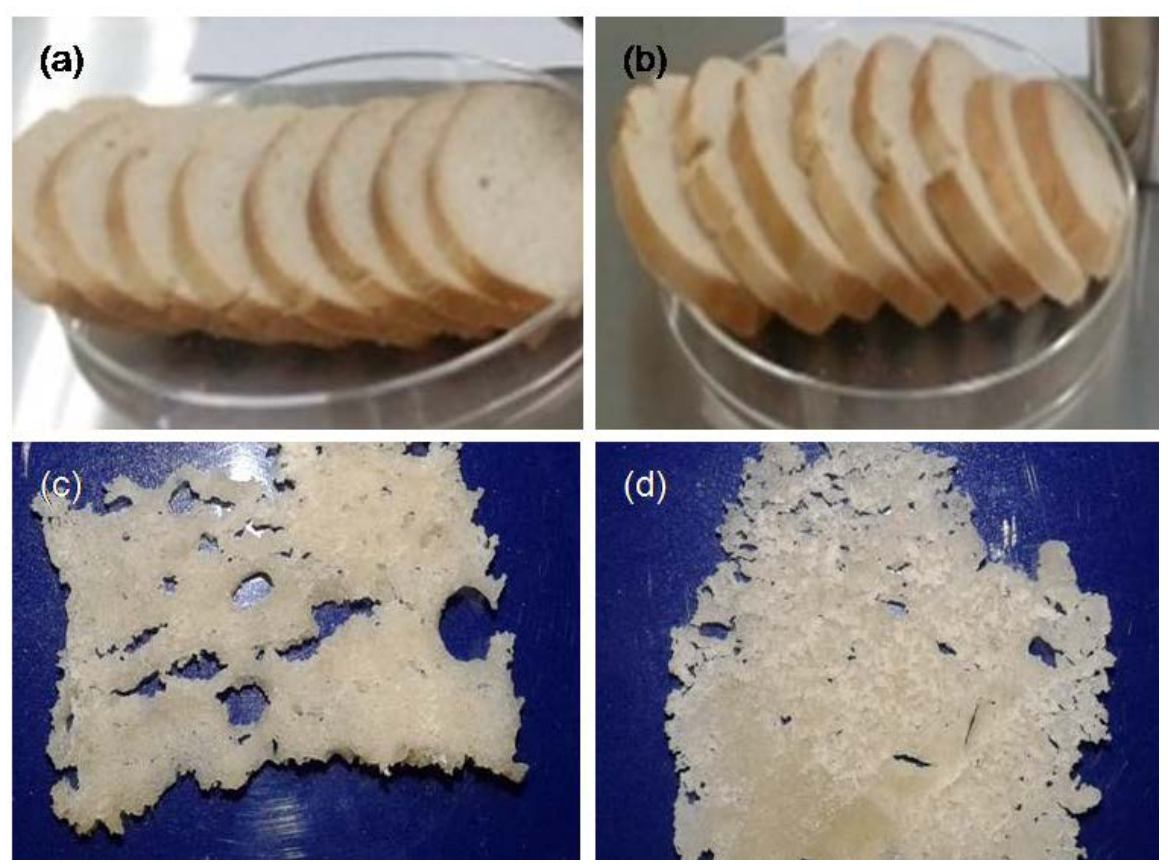

Figure 2. Plates showing ((a), (c)) control bread and ((b), (d)) carrageenan-supplemented bread indicating their porosity.

properties of the flour (WHC-1.33 g/g; SC-3.50 ml/g). Even though, the loaf weight $(140.13 \mathrm{~g})$ was high in carrageenan-substituted bread, the loaf volume 
$(130.0 \mathrm{ml})$ reduced considerably in the same. The fat $(4.6 \mathrm{~g} \%)$ and protein content $(7.0 \mathrm{~g} \%)$ were enhanced in carrageenan-substituted bread. Carrageenan-substitution significantly improved the fiber content in the bread (9.4 g\%). The mineral contents, $\mathrm{Na}, \mathrm{K}, \mathrm{Mg}, \mathrm{Ca}, \mathrm{Fe}$, and $\mathrm{Zn}$, were increased with the incorporation of carrageenan. The color analysis showed that carrageenan substitution did not alter the color of the product. Incorporation of carrageenan also softened the bread texture and improved the springiness. The present attempt could encourage the use of marine fibers in developing functional foods and exploiting the health benefits of these bioactive components. The use of these bioactives in composite foods will ensure nutritional efficacy and health foods for the growing population

\section{Acknowledgements}

Acknowledgement due to Mr. Pulkit Jain, Aquarev Industries (Una, Gujarat, India) for supplying the carrageenan (food grade) sample packs. The Centre also acknowledges Dr. Anu Gopinath for her assistance in analyzing the samples for mineral contents. The authors also extend their sincere acknowledgement to Ms. Indu P. for assisting in the study.

\section{Conflicts of Interest}

The authors declare no conflicts of interest regarding the publication of this paper.

\section{References}

[1] Tebben, L., Shen, Y. and Li, Y. (2018) Improvers and Functional Ingredients in Whole Wheat Bread: A Review of Their Effects on Dough Properties and Bread Quality. Trends in Food Science \& Technology, 81, 10-24. https://doi.org/10.1016/j.tifs.2018.08.015

[2] Gawlik-Dziki, U., Dziki, D., Baraniak, B. and Lin, R. (2009) The Effect of Simulated Digestion in Vitro on Bioactivity of Wheat Bread with Tartary Buckwheat Flavones Addition. LWT-Food Science and Technology, 42, 137-143. https://doi.org/10.1016/j.lwt.2008.06.009

[3] Das, A., Raychaudhuri, U. and Chakraborty, R. (2011) Cereal Based Functional Food of Indian Subcontinent: A Review. Journal of Food Science and Technology, 49, 665-672. https://doi.org/10.1007/s13197-011-0474-1

[4] Rahaie, S., Gharibzahedi, S.M.T., Razavi, S.H. and Jafari, S.M. (2014) Recent Developments on New Formulations Based on Nutrient-Dense Ingredients for the Production of Healthy-Functional Bread: A Review. Journal of Food Science and Technology, 51, 2896-2906. https://doi.org/10.1007/s13197-012-0833-6

[5] Gómez-Diaz, D. and Navaza, J.M. (2003) Rheology of Aqueous Solutions of Food Additives: Effect of Concentration, Temperature and Blending. Journal of Food Engineering, 56, 387-392. https://doi.org/10.1016/S0260-8774(02)00211-X

[6] Kadam, S.U. and Prabhasankar, P. (2010) Marine Foods as Functional Ingredients in Bakery and Pasta Products. Food Research International, 43, 1975-1980. https://doi.org/10.1016/j.foodres.2010.06.007 
[7] Das, L., Raychaudhuri, U. and Chakraborty, R. (2013) Role of Hydrocolloids in Improving the Physical and Textural Characteristics of Fennel Bread. International Food Research Journal, 20, 2253.

[8] Guarda, A., Rosell, C.M., Benedito, C. and Galotto, M.J. (2004) Different Hydrocolloids as Bread Improvers and Antistaling Agents. Food Hydrocolloids, 18, 241-247. https://doi.org/10.1016/S0268-005X(03)00080-8

[9] Lima, I., Guaraya, H. and Champagne, E. (2002) The Functional Effectiveness of Reprocessed Rice Bran as an Ingredient in Bakery Products. Food/Nahrung, 46, 112-117. https://doi.org/10.1002/1521-3803(20020301)46:2<112::AID-FOOD112>3.0.CO;2-N

[10] Ak, T. and Gulcin, I. (2008) Antioxidant and Radical Scavenging Properties of Curcumin. Chemico-Biological Interactions, 174, 27-37. https://doi.org/10.1016/j.cbi.2008.05.003

[11] Lim, J., Seo, B.J., Kim, J.E., Chae, C.S., Im, S.H. and Hahn, Y.S. (2011) Characteristics of Immunomodulation by a Lactobacillus sakei proBio65 Isolated from Kimchi. Korean Journal of Microbiology and Biotechnology, 39, 313-316.

[12] Bajerska, J., Jeszka, J., Tarnowska, A.K. and Czlapka-Matyasik, M. (2010) The Effect of Green and Oolong Tea Extracts Supplementation on Body Composition in Wrestlers. Pakistan Journal of Nutrition, 9, 696-702. https://doi.org/10.3923/pjn.2010.696.702

[13] Peng, X., Ma, J., Cheng, K.W., Jiang, Y., Chen, F. and Wang, M. (2010) The Effects of Grape Seed Extract Fortification on the Antioxidant Activity and Quality Attributes of Bread. Food Chemistry, 119, 49-53. https://doi.org/10.1016/j.foodchem.2009.05.083

[14] Harmsen, H.J., Raangs, G.C., Franks, A.H., Wildeboer-Veloo, A.C. and Welling, G.W. (2002) The Effect of the Prebiotic Inulin and the Probiotic Bifidobacterium longum on the Fecal Microflora of Healthy Volunteers Measured by FISH and DGGE. Microbial Ecology in Health and Disease, 14, 8246. https://doi.org/10.3402/mehd.v14i4.8246

[15] Korus, J., Grzelak, K., Achremowicz, K. and Sabat, R. (2006) Influence of Prebiotic Additions on the Quality of Gluten-Free Bread and on the Content of Inulin and Fructo-Oligosaccharides. Food Science and Technology International, 12, 489-495. https://doi.org/10.1177/1082013206073072

[16] Yaseen, A.A., Shouk, A.A. and Ramadan, M.T. (2010) Corn-Wheat Pan Bread Quality as Affected by Hydrocolloids. Journal of American Science, 6, 684-790.

[17] Lee, M.H., Baek, M.H., Cha, D.S., Park, H.J. and Lim, S.T. (2002) Freeze-Thaw Stabilization of Sweet Potato Starch Gel by Polysaccharide Gums. Food Hydrocolloids, 16, 345-352. https://doi.org/10.1016/S0268-005X(01)00107-2

[18] Albert, S. and Mittal, G.S. (2002) Comparative Evaluation of Edible Coating to Reduce Fat Uptake in a Deep-Fried Cereal Product. Food Research International, 35, 445-458. https://doi.org/10.1016/S0963-9969(01)00139-9

[19] Ikeda, S., Sandu, T. and Nishinari, K. (2003) Comparative Studies on Fracture Characteristics of Food Gels Subjected to Uniaxial Compression and Torsion. Food Science and Technology Research, 9, 372-377. https://doi.org/10.3136/fstr.9.372

[20] Ganesan, P., Kumar, C.S. and Bhaskar, N. (2008) Antioxidant Properties of Methanol Extract and Its Solvent Fractions Obtained from Selected Indian Red Seaweeds. Bioresource Technology, 99, 2717-2723. https://doi.org/10.1016/j.biortech.2007.07.005 
[21] Raman, M. and Doble, M. (2015) $\kappa$-Carrageenan from Marine Red Algae, Kappaphycusalvarezii-A Functional Food to Prevent Colon Carcinogenesis. Journal of Functional Foods, 15, 354-364. https://doi.org/10.1016/j.jff.2015.03.037

[22] Japan Food Additives Association (2009) Japan's Specifications for Food Additives. 8th Edition, the Ministry of Health and Welfare, 344.

[23] http://www.fao.org/fileadmin/user_upload/agns/news_events/JECFA\%2079\%20Su mmary\%20Version\%20Final.pdf

[24] https://www.ams.usda.gov/sites/default/files/media/Carrageenan\%20TR\%202_10_1 6.pdf

[25] EFSA Panel on Food Additives and Nutrient Sources added to Food (ANS), Younes, M., Aggett, P., Aguilar, F., Crebelli, R., Filipič, M., Kuhnle, G.G., et al. (2018) Re-Evaluation of Carrageenan (E 407) and Processed Eucheuma Seaweed (E 407a) as Food Additives. EFSA Journal, 16, e05238. https://doi.org/10.2903/j.efsa.2018.5238

[26] Rosell, C.M., Rojas, J.A. and De Barber, C.B. (2001) Influence of Hydrocolloids on Dough Rheology and Bread Quality. Food Hydrocolloids, 15, 75-81.

https://doi.org/10.1016/S0268-005X(00)00054-0

[27] Rojas, J.A., Rosell, C.M. and De Barber, C.B. (1999) Pasting Properties of Different Wheat Flour-Hydrocolloid Systems. Food Hydrocolloids, 13, 27-33. https://doi.org/10.1016/S0268-005X(98)00066-6

[28] https://www.cornucopia.org/wp-content/uploads/2016/04/CarageenanReport-2016. pdf

[29] AACC (2000) Approved Methods of American Association of Cereal Chemists. AACC Inc., St. Paul, 2-52, 10-10B.

[30] Onipe, O.O., Beswa, D. and Jdeani, A.I.O. (2017) Effect of Size Reduction on Color, Hydration and Rheological Properties of Wheat Bran. Food Science and Technolo$g y$, 37, 389-396. https://doi.org/10.1590/1678-457x.12216

[31] Elkhalifa, A.E.O. and Bernhardt, R. (2010) Influence of Grain Germination on Functional Properties of Sorghum Flour. Food Chemistry, 121, 387-392. https://doi.org/10.1016/j.foodchem.2009.12.041

[32] Hallén, E., İbanoğlu, Ş. and Ainsworth, P. (2004) Effect of Fermented/Germinated Cowpea Flour Addition on the Rheological and Baking Properties of Wheat Flour. Journal of Food Engineering, 63, 177-184. https://doi.org/10.1016/S0260-8774(03)00298-X

[33] AOAC (2000) Official Methods of Analysis. Association of Official Analytical Chemists International. 17th Edition, Gaithersburg.

[34] Dubois, M., Gilles, K.A., Hamilton, J.K., Rebers, P.T. and Smith, F. (1956) Colorimetric Method for Determination of Sugars and Related Substances. Analytical Chemistry, 28, 350-356. https://doi.org/10.1021/ac60111a017

[35] Dare, P.J. and Edwards, D.B. (1975) Seasonal Changes in Flesh Weight and Biochemical Composition of Mussels (Mytilus edulis L.) in the Conwy Estuary, North Wales. Journal of Experimental Marine Biology and Ecology, 18, 89-97. https://doi.org/10.1016/0022-0981(75)90066-0

[36] Lane, J.H. and Eynon, L. (1923) Methods for Determination of Reducing and Non-Reducing Sugars. Journal of Sciences, 42, 32-37.

[37] Hortwitz, W. (1960) Official Methods of Analysis. 8th Edition, Associates of Official Agriculture Chemists Inc., Washington DC.

[38] Sayed-Ahmad, B., Talou, T., Straumite, E., Sabovics, M., Kruma, Z., Saad, Z., Me- 
rah, O., et al. (2018) Evaluation of Nutritional and Technological Attributes of Whole Wheat Based Bread Fortified with Chia Flour. Foods, 7, 135.

https://doi.org/10.3390/foods7090135

[39] Techawipharat, J., Suphantharika, M. and BeMiller, J.N. (2008) Effects of Cellulose Derivatives and Carrageenans on the Pasting, Paste, and Gel Properties of Rice Starches. Carbohydrate Polymers, 73, 417-426. https://doi.org/10.1016/j.carbpol.2007.12.019

[40] Martínez, M.M., Macias, A.K., Belorio, M.L. and Gómez, M. (2015) Influence of Marine Hydrocolloids on Extruded and Native Wheat Flour Pastes and Gels. Food Hydrocolloids, 43, 172-179. https://doi.org/10.1016/j.foodhyd.2014.05.012

[41] Sharadanant, R. and Khan, K. (2003) Effect of Hydrophilic Gums on the Quality of Frozen Dough: II. Bread Characteristics. Cereal Chemistry, 80, 773-780. https://doi.org/10.1094/CCHEM.2003.80.6.773

[42] Kohajdová, Z. and Karovičová, J. (2009) Application of Hydrocolloids as Baking Improvers. Chemical Papers, 63, 26-38. https://doi.org/10.2478/s11696-008-0085-0

[43] Pečivová, P., Juř́íková, K., Burešová, I., Černá, M. and Hrabě, J. (2011) The Effect of Pectin from Apple and Arabic Gum from Acacia Tree on Quality of Wheat Flour Dough. Acta Universitatis Agriculturae et Silviculturae Mendelianae Brunensis, 59, 255-264. https://doi.org/10.11118/actaun201159060255

[44] Ragaee, S. and Abdel-Aal, E.S.M. (2006) Pasting Properties of Starch and Protein in Selected Cereals and Quality of Their Food Products. Food Chemistry, 95, 9-18. https://doi.org/10.1016/j.foodchem.2004.12.012

[45] Zghal, M.C., Scanlon, M.G. and Sapirstein, H.D. (2002) Cellular Structure of Bread Crumb and Its Influence on Mechanical Properties. Journal of Cereal Science, 36, 167-176. https://doi.org/10.1006/jcrs.2001.0445

[46] Rodge, A.B., Sonkamble, S.M., Salve, R.V. and Hashmi, S.I. (2012) Effect of Hydrocolloid (Guar Gum) Incorporation on the Quality Characteristics of Bread. Journal of Food Processing and Technology, 3, 133-120.

[47] Mikuš, L., Valík, L. and Dodok, L. (2014) Usage of Hydrocolloids in Cereal Technology. Acta universitatis agriculturae et silviculturae Mendelianae Brunensis, 59, 325-334. https://doi.org/10.11118/actaun201159050325

[48] Azizi, M.H. and Rao, G.V. (2004) Effect of Surfactant Gel and Gum Combinations on Dough Rheological Characteristics and Quality of Bread. Journal of Food Quality, 27, 320-336. https://doi.org/10.1111/j.1745-4557.2004.00600.x

[49] Mandala, I., Karabela, D. and Kostaropoulos, A. (2007) Physical Properties of Breads Containing Hydrocolloids Stored at Low Temperature. I. Effect of Chilling. Food Hydrocolloids, 21, 1397-1406. https://doi.org/10.1016/j.foodhyd.2006.11.007

[50] Davidou, S., Le Meste, M., Debever, E. and Bekaert, D. (1996) A Contribution to the Study of Staling of White Bread: Effect of Water and Hydrocolloid. Food Hydrocolloids, 10, 375-383. https://doi.org/10.1016/S0268-005X(96)80016-6

[51] Majzoobi, M., Farahnaky, A. and Ostovan, R. (2008) Effects of Microcrystalline Cellulose and Hydroxypropylmethyl Cellulose on the Properties of Dough and Flat Bread (Iranian Barbari Bread). Iran Agricultural Research, 25, 87-98. 